University of Nebraska - Lincoln

DigitalCommons@University of Nebraska - Lincoln

USDA National Wildlife Research Center - Staff Publications
U.S. Department of Agriculture: Animal and Plant Health Inspection Service

2011

\title{
Hematozoa and a New Haemoproteid Species from Cathartidae (New World Vulture) in South Carolina
}

Ellis C. Greiner

University of Florida, greinere@ufl.edu

Alan M. Fedynich

Texas A \& M University - Kingsville

Stephen L. Webb

Purdue University

Travis L. DeVault

USDA/APHIS/WS National Wildlife Research Center, Travis.L.DeVault@aphis.usda.gov

Olin E. Rhodes Jr.

U.S. Department of Agriculture, rhodes@srel.uga.edu

Follow this and additional works at: https://digitalcommons.unl.edu/icwdm_usdanwrc

Part of the Life Sciences Commons

Greiner, Ellis C.; Fedynich, Alan M.; Webb, Stephen L.; DeVault, Travis L.; and Rhodes, Olin E. Jr., "Hematozoa and a New Haemoproteid Species from Cathartidae (New World Vulture) in South Carolina" (2011). USDA National Wildlife Research Center - Staff Publications. 1309.

https://digitalcommons.unl.edu/icwdm_usdanwrc/1309

This Article is brought to you for free and open access by the U.S. Department of Agriculture: Animal and Plant Health Inspection Service at DigitalCommons@University of Nebraska - Lincoln. It has been accepted for inclusion in USDA National Wildlife Research Center - Staff Publications by an authorized administrator of DigitalCommons@University of Nebraska - Lincoln. 


\title{
HEMATOZOA AND A NEW HAEMOPROTEID SPECIES FROM CATHARTIDAE (NEW WORLD VULTURE) IN SOUTH CAROLINA
}

\author{
Ellis C. Greiner, Alan M. Fedynich*, Stephen L. Webb†, Travis L. DeVaultł§, and Olin E. Rhodes, Jr.ł川 \\ Department of Infectious Diseases and Pathology, College of Veterinary Medicine, University of Florida, Gainesville, Florida 32611. \\ e-mail: greinere@ufl.edu
}

\begin{abstract}
A survey of turkey vultures (Cathartes aura) in South Carolina revealed the presence of a novel haemoproteid. Haemoproteus catharti $\mathrm{n}$. sp. is described from the slides developed from the blood of this vulture. The new species is a thick, halteridial form with complete margins, and is considered distinct from the other recognized haemoproteids from the diurnal raptors in shape, pigment number, parasite outline, and host-family specificity. While reviewing blood films, a series of unusual immature schizonts of Plasmodium sp. were also observed, and these are illustrated, along with another distinct haemoproteid from old slides of poor quality produced from turkey vulture blood.
\end{abstract}

The taxonomy of Haemoproteus is based on morphology and host specificity at the avian host family level (Pierce, 2005). Pierce et al. (1990) reviewed the known species of Haemoproteus in the Falconiformes and his summary was used for comparison with our proposed new species. Genetic sequences do not always support this tradition, as sometimes the same nucleic acid sequences of haemoproteids are found in birds from different families (Fallon et al., 2003; Krizanauskiene et al., 2006; Svensson and Ricklefs, 2009). Until experimental infections are completed to determine the true extent of host specificity, we should use the conservative approach that discovery of a haemoproteid in an avian family with no prior species named is justification for proposing a new species name. This is a better option than only providing a generic name because it provides more information for future work. If synonyms are discovered, the science will be corrected. If no species name is provided, useful information may be lost.

Webb et al. (2005) examined 22 black vultures (Coragyps atratus) and 11 turkey vultures (Cathartes aura) and determined that 1 was infected with a species of Haemoproteus. They reviewed the literature of blood parasites from new world vultures and found that Haemoproteus spp. prevalence varied in turkey vultures from 14/79 (18\%) (Wetmore, 1941) in Washington, D.C., 2/9 (12\%) in Maryland and New Jersey (Williams and Bennett, 1978), 3/4 (75\%) in Panama (Galindo and Sousa, 1966), Georgia (Love et al., 1953), and Panama (Darling, 1912). Black vultures were rarely found with patent hematozoan infections. The primary purpose of the present article is to name the previously undescribed taxon from the turkey vulture.

\section{MATERIALS AND METHODS}

Vultures were trapped in baited walk-in traps and by rocket nets at the Savannah River Site, a United Stated States Department of Energy nuclear production and research facility near Aiken, South Carolina (DeVault et al., 2004, 2005). While the birds were being handled for placement of radio transmitters, blood samples were collected from the

Received 10 September 2009; revised 25 January 2011, revised 15 July 2011, revised 22 July 2011; accepted 29 July 2011.

* Caesar Kleburg Wildlife Research Institute, Texas A \& M UniversityKingsville, Kingsville, Texas 78363.

$\dagger$ Department of Forestry and Natural Resources, Purdue University, West Lafayette, Indiana 47097.

\$Hayden-Wing Associates, Laramie, Wyoming 82072.

$\S U . S$. Department of Agriculture, Wildlife Services, National Wildlife Research Center, 6100 Columbus Avenue, Sandusky, Ohio 44870.

|lU.S. Department of Agriculture, Wildlife Services, National Wildlife Research Center, 4101 LaPorte Avenue, Fort Collins, Colorado 80521. DOI: 10.1645/GE-2332.1 brachial vein. Blood smears were made on site and the slides were methanol fixed and stained with Diff-Quik (Webb et al., 2005). Positive smears were sent to the University of Florida for identification of the parasite. Gametocytes were photographed with an Olympus DP25 Digital Camera on a Zeiss compound microscope under oil immersion; images were printed, and then measured by superimposing a grid of known size to match the print magnifications. Standard deviations and means of measurements were made with Sigma Stat 2.03. All measurements are in microns.

\section{DESCRIPTION}

\section{Haemoproteus catharti $\mathrm{n} . \mathrm{sp}$.}

(Figs. 1-4)

Immature gametocytes: Elongate; immature gametocytes develop lateral to erythrocyte nucleus (Fig. 1).

Macrogametocytes $(n=20)$ : Thick, halteridial gametocytes with complete margins infect mature erythrocytes; usually longer than length of RBC (Figs. 2, 3). Gametocytes partially displace host cell nucleus (nuclear displacement ratio $[\mathrm{NDR}]=0.59 \pm 0.2[0.2-1.0]$ ); gametocyte length $15.4 \pm 1.1(14-18)$, width $3.4 \pm 0.5(2.5-5=4)$, and area $56.9 \pm 8.3$ (43-74). Nucleus centrally located; gametocytes not usually in contact with red-blood-cell nucleus. Normal staining differentiation with macrogametocytes a darker blue and microgametocytes faintly staining. Infected red blood cell slightly hypertrophied, with length $15.4 \pm 1.0$ (14-17), width $7.7 \pm 0.7$ (7-9), and area $96.8 \pm 10.382-115)$. Pigment granule number $24.4 \pm 7.0$ (19-33), highly refractive, moderately sized, and scattered throughout gametocytes.

Microgametocytes $(n=3)$ : Thick, halteridial gametocytes with entire margins infecting mature erythrocytes (Fig. 4), usually bending around ends of red-blood-cell nucleus; usually not in contact with red-blood-cell nucleus. Gametocytes partially displace erythrocyte nucleus $(\mathrm{NDR}=0.5$ \pm 0.2 [0.3-0.7]). Gametocyte length $14.5 \pm 0.6$ (14-15), width $3.7 \pm 0.6$ (3-4), and area $55.0 \pm 7.0(48-62)$. Infected erythrocytes length $15.2 \pm 1.3$ (14-16.5), width $7.8 \pm 0.8$ (7-8.5), and area $93.3 \pm 16.3$ (75-106); slightly hypertrophied. Pigment granule number $18.0 \pm 7.0$ (11-25), with similar traits of macrogametocyte.

Uninfected erythrocytes $(n=10)$ : Length $14.2 \pm 0.8(13-16)$, width 7.9 $\pm 0.5(7-9)$, and area $88.6 \pm 10.9(71-119)$.

\section{Taxonomic summary}

Type host: Cathartes aura turkey vulture.

Type locality: Savannah River Site, Aiken, South Carolina $\left(33^{\circ} 16^{\prime} \mathrm{N}\right.$, $\left.81^{\circ} 34^{\prime} \mathrm{W}\right)$

Basis for description: Parasites are described from 2 blood smears taken from a turkey vulture collected at the Savannah River Site by T. L. DeVault on 28 June 2001.

Specimens deposited: The hepantotype and the parahepantotype are deposited in the International Reference Centre for Avian Haematozoa (IRCAH) in Queensland Museum, South Brisbane, Queensland, Australia G465453and G465454, respectively.

Distribution: It is presumed that this taxon is present throughout the range of the Cathartidae.

Etymology: The parasite-specific epithet is a reflection of the family of birds it infects. 


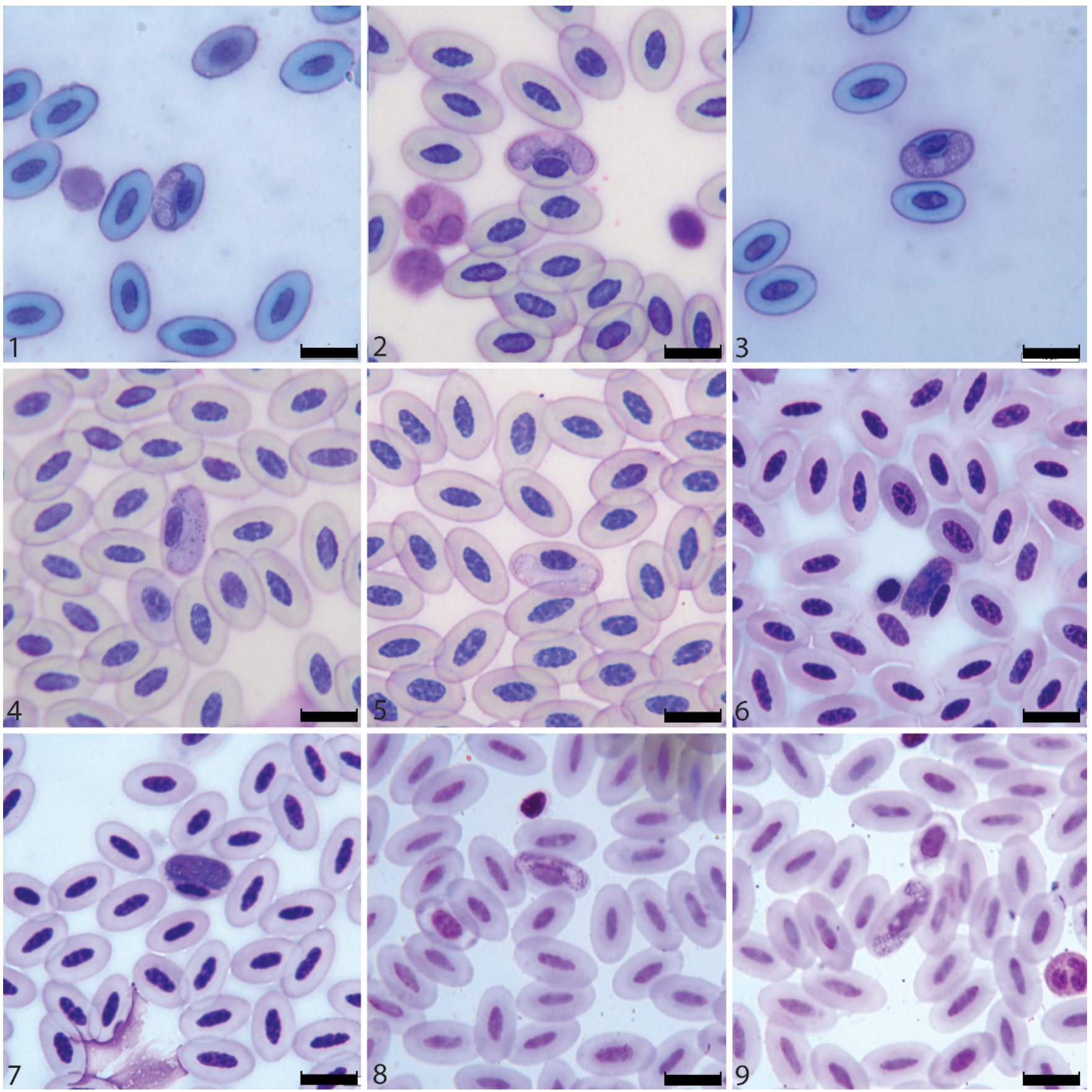

Figures 1-9. Haemoproteus catharti gametocyte. (1) Immature macrogametocyte (size bar $=10 \mu \mathrm{m}$, same for all figures). (2) Macrogametocyte in contact with RBC nucleus. (3) Macrogametocyte not in contact with RBC nucleus. (4) Thicker variety of microgametocyte. (5) Microgametocyte $(6,7)$ Plasmodium sp. immature schizont. (8,9) Haemoproteus sp. or Plasmodium sp. slender, less halteridial macrogametocyte.

\section{Remarks}

This is the first species named from vultures in the Cathartidae. The new species resembles Haemoproteus tinnunculi (Wasielewski and Wulker, 1918) Wingstrand, 1947 (see Figs. 2 and 3 of Pierce et al., 1990), which is a parasite of the Falconidae and Haemoproteus elani de Mello, 1937 (see Figs. 6 and 7 of Pierce et al., 1990) of the Accipitridae, although we observed no volutin granules in the gametocytes of the blood smears. The new species has complete margins, unlike both Haemoproteus nisi Pierce and Marquiss, 1983 of the Accipitridae and Haemoproteus brachiatus Valkiūnas and Ezhova, 1989 of Falconidae, which have thin gametocytes with amoeboid or incomplete margins. The new species does not have circumnuclear, or broadly ovate, gametocytes as does, Haemoproteus janovyi Greiner and Mandal, 1979 of the Accipitridae.

Three slides from turkey vultures originating from Maryland (C.M. Herman collected in 1940), were borrowed from IRCAH, although the quality of these slides was poor. One smear (53216), however, contained a taxon with thinner gametocytes (Figs. 8, 9), with fewer pigment granules, entire margins, and usually straighter gametocytes than $H$. catharti $\mathrm{n}$. sp.; some were halteridial and the NDR was about 1.0. This parasite does not fit the morphology of any of the known species from diurnal raptors (Pierce et al., 1990), but the limited material available for study precluded us naming it. Whether this is a second species of Haemoproteus or possibly represents a second species of Plasmodium, possibly Plasmodium 
elongatum Huff, 1930 (see Valkiūnas, 2005 Figs. 273:16-17), in which no schizonts were detected, is not clear. The other 2 slides could not be used because of the faint stain of one and no parasites were seen on the other. We do not have molecular data on any of these species and thus feel justified in naming $H$. catharti based mainly on host specificity at the avian-host family level and its morphology.

In rescanning the slides trying to find specimens of immature forms to photograph, we discovered that there was also a series of unusually thick, elongate immature schizonts lateral to the red-blood-cell nucleus (Figs. 6, 7). These immature schizonts were most similar to Plasmodium circumflexum (Kikuth, 1931) (see Valkiūnas, 2005 Figs. 240-247) and Plasmodium gabaldoni Garnham, 1977 (see Valkiūnas, 2005, Figs. 254 256). Species identifications are not based on immature schizonts, and thus the species could not be determined.

\section{DISCUSSION}

The new world vultures are infected with blood parasites. No species of Haemoproteus has, however, been named from this family of birds, and until it is determined that this parasite is a synonym of a preexisting species, we propose the name $H$. catharti n. sp. for the broad halteridial species that infects cathartids. There may be a second species as suggested by the morphology of gametocytes on one of the early smears from Maryland, but until better-quality slides are available, it will not be named.

\section{ACKNOWLEDGMENTS}

Funding for capturing vultures was provided by DABT63-96-D-0006 between Purdue University and the United States Air Force Bird/Wildlife Aircraft Strike Hazard Team. We acknowledge the support from the United States Department of Energy through contract DE-FC0996SR18546 with the University of Georgia's Savannah River Ecology Laboratory, The Caesar Kleberg Wildlife Research Institute and Purdue University, Department of Forestry and Natural Resources. We thank A. L. Bryan for aid in trapping vultures.

\section{LITERATURE CITED}

DARLING, S. T. 1912. Some blood parasites (Haemoproteus and Haemogregarina). Bulletin de al Societe de Pathologie et de ses Filiales 5: 71-73.
Devault, T. L., B. D. Reinhart, I. L. Brisbin, and O. E. Rhodes Jr. 2004. Home ranges of sympatric black and turkey vultures in South Carolina. Condor 106: 706-711.

,--1, AND $\longrightarrow$ 2005. Flight behavior of black and turkey vultures: Implications for reducing bird-aircraft collisions. Journal of Wildlife Management 69: 601-608.

Fallon, S. M., E. Bermingham, and R. E. Ricklefs. 2003. Island and taxon effects in parasitism revisited: Avian malaria in the Lesser Antilles. Evolution 57: 606-615.

Galindo, P., AND O. Sousa. 1966. Blood parasites of birds from Almirante, Panama with ecological notes on their hosts. Revista Biologica 14: 27-46.

Krizanauskiene, A., O. Hellgren, V. Kosarev, L. Sokolov, S. Bensch, AND G. VALKIŪNAs. 2006. Variation in host specificity between species of avian hemosporidian parasites: Evidence from parasite morphology and cytochrome B gene sequences. Journal of Parasitology 92: 1319-1334.

Love, G. T., S. A. Wilkin, And M. H. Goodwin. 1953. Incidence of blood parasites in birds collected in southwestern Georgia. Journal of Parasitology 39: 52-57.

Pierce, M. A. 2005. A checklist of valid avian species of Babesia (Apicomplexa: Piroplasmorida), Haemoproteus, Leucocytozoon (Apicomplexa: Haemosporida), and Hepatozoon (Apicomplexa: Haemogregarinidae). Journal of Natural History 39: 3621-3632.

, G. F. Bennett, And M. Bishop. 1990. The haemoproteids of the avian order Falconiformes. Journal of Natural History 24: 10911100 .

Svensson, L. M. E., And R. E. Ricklefs. 2009. Low diversity and high intra-island variation in prevalence of Haemoproteus parasites on Barbados, Lesser Antilles. Parasitology 136: 11211131.

VALKIUUNAS, G. 2005. Avian malaria parasites and other Haemosporidia. CRC Press, Boca Raton, Florida, 935 p.

Webb, S. L., A. M. Fedynich, S. K. Yeltatzi, T. L. De Vault, and O. E. Rhodes. 2005. Survey of blood parasites in black vulture and turkey vultures from South Carolina. Southeastern Naturalist 4: $355-360$.

Wetmore, P. W. 1941. Blood parasites of birds of the District of Columbia and Patuxent Research Refuge vicinity. Journal of Parasitology 27: 379-393.

Williams, N. A., and G. F. Bennett. 1978. Hematozoa of some birds of New Jersey and Maryland. Canadian Journal of Zoology 56: 596-603. 